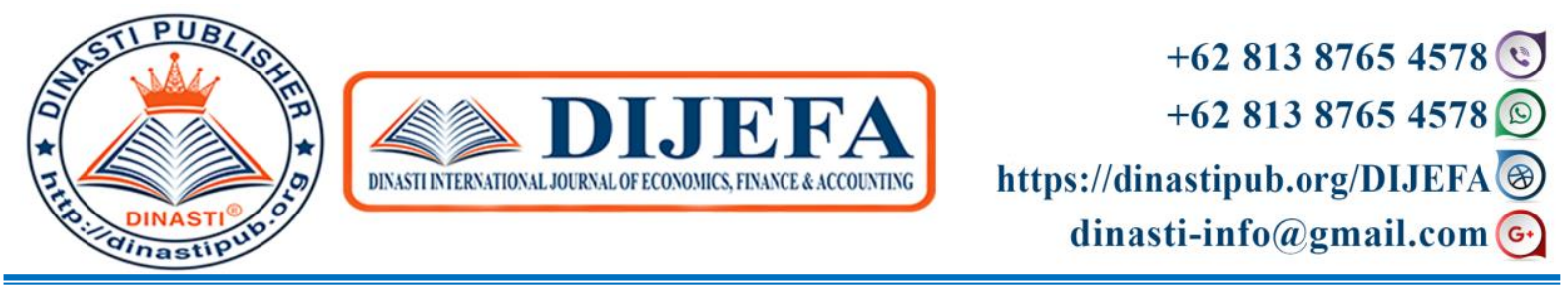

\title{
INVESTMENT BEHAVIOR IN GENERATION Z AND MILLENNIAL GENERATION
}

\author{
Riska Rosdiana ${ }^{1}$ \\ 1) Universitas Mercu Buana, Jakarta, Indonesia, riska.rosdiana@mercubuana.ac.id
}

ARTICLE INFORMATION

Received: 29 September 2020

Revised: 15 October 2020

Issued: 12 November 2020

Corresponding author:

E-mail:

riska.rosdiana@mercubuana.ac.id

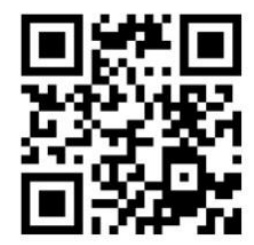

DOI: 10.38035/DIJEFA
Abstract : The purpose of this study was to determine the effect of the level of financial literacy, herding behavior, risk-averse, risk perception on investment decisions in the $\mathrm{Z}$ generation, and the Millennial generation. Respondents are academicians in the Faculty of Economics and Business, Mercu Buana University who already have income, which includes: Lecturers, Staff, and Students aged 15 - 39 years. Determination of the sample using non-probability sampling with an accidental sampling approach. Data were analyzed using Multiple Linear Regression Analysis. The results showed that financial literacy, herding behavior, risk-averse, risk perception have a positive effect on investment decisions.

Keywords: Financial Literacy, Herding Behavior, Risk-Averse, Risk Perception, Investment Decisions.

\section{INTRODUCTION}

Millennials are the first generation to see the internet as a great invention and change everything. This generation was born when the internet and social media became everyday things. The demographic bonus conditions in the productive age which are very high and the characteristics of the millennial generation who are attached to technology are then used by ecommerce companies for promotion. The term millennial was first coined by William Strauss and Neil in their book Millennials Rising: The Next Great Generation (2000). They coined this term in 1987 when children born in 1982 entered pre-school. At that time the media began to call it a group connected to the new millennium upon graduating from high school in 2000 .

Besides the generation before the millennial generation, there is a generation after the millennial generation called Generation Z which was born between 2001 and 2010. Generation $\mathrm{Z}$ is a transition from Generation $\mathrm{Y}$ or the millennial generation at a time when technology is rapidly developing. The Generation $\mathrm{Z}$ mindset tends to be instantaneous. Generation $\mathrm{Z}$ and the millennial generation are digital generations that easily absorb any 
information from the internet, apart from easy access in terms of daily consumption, this generation was born in an era with easy access to financial institutions, so ideally it's easy to learn about the financial sector. fast and apply it to life. To invest, generation $\mathrm{Z}$ and millennials only need to access everything they need via the internet on their gadgets. Millennials are not only facing increasing complexity in financial products, services, and markets, but they are more likely to have to bear greater financial risk in the future. The national economy will not be easily swayed or affected by various world financial crises if people understand the financial system. Bad things that might happen in the future can be overcome by doing financial planning, so financial planning is needed from an early age. Planning is made to anticipate almost all possibilities that occur. Planning is needed so that people can achieve financial goals as a whole and cover the entire life cycle, from now to the end. Without proper and careful planning, financial chaos can occur. It also requires discipline and proper control.

The phenomenon that has recently been evident in plain sight is the growing consumptive nature of consumers towards consumer goods. The progress of the development of technology and information makes people feel they need all the goods offered by producers, the growing consumptive attitude of the community is supported by the ease of payment transactions offered by financing institutions such as banks (Parmariza and Juniarti, 2017).

The World Bank shows that Indonesia's financial literacy rate is only around $29.7 \%$. This is lower than ASEAN countries such as Malaysia 66\%, Thailand 73\%, and Singapore at 98\%. Besides, based on the 2017 Indonesian financial literacy strategy report (SNLKI), the 2016 Indonesian Public Financial Literacy Index by Province shows that DKI Jakarta has a financial literacy index above the national average, reaching 40\% (SNLKI OJK, 2017)

With the above phenomena, generation $\mathrm{Z}$ and millennial generations must have financial intelligence, namely the ability to carry out financial planning and investment decision making. The focus of the discussion in this study is to measure the effect of financial literacy, herding behavior, risk-averse, and risk perception on investment decisions of generation $\mathrm{Z}$ and the millennial generation.

\section{LITERATURE REVIEW}

The most basic things in an investment decision are return and risk. Because understanding the relationship between the expected return (return) with the risk (risk) received from the investment made is a unidirectional relationship (Linear). This means that the greater the expected profit, the greater the risk that must be faced. So that investors to minimize the risk of investing need to understand rationally and be careful in the decisionmaking process (Pratiwi \& Prijati, 2015).

\section{Financial Literacy}

Financial Literacy is a key that must be considered when a person's ability to make good investment decisions is questionable and financial literacy results in better financial decisions (Ates et al, 2016). The term financial literacy describes an individual's ability to solve financial problems appropriately and successfully. In general, financial literacy 
discusses a person's income, its sources, and the effective and efficient use of their income, spending income by making confident decisions about savings or savings according to the situation (Hussain \& Sajjad, 2016).

\section{Herding Behavior}

According to Liem \& Sukamulja (2017) herding behavior is a follow-up behavior that one investor follows another investor for various reasons and conditions. This behavior is the most common mistake in which investors tend to follow the majority in making investment decisions. The influence of the people around them is the main reason an investor has herding behavior. A person with herding behavior is easily influenced by other people's decisions and has an impact on changes in investment decisions taken (Gozalie \& Anastasia, 2015).

\section{Risk Averse}

Risk-Averse is the attitude of an investor who avoids risk or it can be said that the investor is only willing to invest if the expected return will be greater than the risk (Sudana \& Sallama, 2015). Investors with the risk averter type have the goal of avoiding losses so as not to make wrong investment decisions (Irjayanti, 2017). According to Farooq \& Sajid (2015), risk-averse can be measured by using indicators, namely, individuals are rational, dare to reject risk, and try to maximize wealth under difficult alternatives.

\section{Risk Perception}

Risk perception is a process of views, assessments, and interpretations of investors on an investment instrument risk regarding investment decisions (Irjayanti, 2017). Every investor has a different assessment of a risk-based on the person's psychological factors. According to Kharta \& Kumar (2014), risk perception is a belief, whether rational or irrational, held by individuals, groups, or society about the likelihood of a risk occurring or about the level, magnitude, and timing of its effects.

Measurement of risk perception is carried out using indicators from Ullah (2015), namely fear of investing in stocks with a definite profit, being careful of sudden stock changes, worrying about investing in stocks with negative performance, and afraid of investing in stocks with a positive performance.

\section{Previous Research}

Arif (2015) conducted a study entitled Financial literacy and other factors Influencing Individuals' Investment Decision: Evidence from a Developing Economy (Pakistan). The results showed that the level of financial literacy from investors was still below average. Besides, the results of the study indicate that financial literacy hurts the number of investment decisions at the $10 \%$ significance level.

Fedorova et al (2015) conducted a study entitled Impact of Financial Literacy of the Population of the Russian Federation on Behavior on Financial Market: Empirical Evaluation. The results show that Russian citizens have a fairly low level of financial literacy. Only 39\% of respondents are financially literate according to a basic level of financial literacy, $29 \%$ of respondents are financially literate, by advanced level, and only 13\% understand the specifics of the Russian stock market. Second, the level of financial literacy of respondents affects their level of participation in the financial market. More and more 
financially educated people are more active in the stock market, investing in retirement savings, and having fewer problem loans in banks.

Lutfi (2010) conducted a study entitled The Relationship Between Demographic Factors and Investment Decision In Surabaya, the results showed that demographic characteristics of investors have a positive correlation with investor behavior and the type of investment chosen. Furthermore, investor risk behavior has a positive correlation with the type of investment. Investors who are risk seekers prefer to invest in capital market instruments, rather than risk averter investors who prefer to put their money into bank accounts and real assets. By investing their funds in risky assets, risk seeker investors can expect higher returns from these assets.

Vijaya (2014) conducted a study entitled "An Empirical Analysis of Influential Factors On Investment Behavior of Retail Investors' in Indian Stock Market: A Behavioral Perspective". The results of the main component analysis revealed that five behavioral factors influence the investment decisions of individual investors in the Indian stock market: Overconfidence, Anchoring, Loss Aversion, Herding, and Market factor. Among the 5 variables overconfidence behavior factors: Knowledge of stocks is important to invest in the stock market has a high impact and variables of other factors have a moderate impact on retail investors' investment decisions in the Indian stock market. The findings suggest that individual investors need to be confident at an acceptable level to utilize their skills and knowledge in certain circumstances to improve investment returns.

Vijaya (2016) conducted a study entitled An Empirical Analysis on Behavioral Pattern of Indian Retail Equity Investors. The results of this study were only three factors found to influence investment performance: herding (including buying and selling; trading stock options; trading stock volume; speed. herding), prospects (including loss aversion, regret aversion, and mental accounting), and heuristics (including overconfidence and gamble's fallacy). Heuristic behavior is found to have the highest positive impact on investment performance while herding behavior positively affects investment performance to a lesser extent. Conversely, prospect behavior hurts investment performance.

Gozalie \& Anastasia, 2015 conducted a study entitled The Effect of Heuristics and Herding Behavior on Residential Property Investment Decision Making. The results showed that heuristics behavior (representativeness, anchoring, gambler's fallacy, and availability bias) had a significant effect on investment decisions. Meanwhile, heuristics (overconfidence) and herding behavior do not have a significant effect on investment decisions.

Ranjbar, M., et al, 2014 entitled Analyzing the Effective Behavioral Factors on the Investors' Performance in Tehran Stock Exchange (Tse). The results show that heuristic and herd behavior methods positively affect investor investment performance. On the other hand, the prospect variable negatively affects the investment performance of investors.

Putri, Ramadhani \& Isbanah, Y (2020) conducted a study entitled Factors That Influence Investment Decisions on Stock Investors in Surabaya, Herding influences investment decisions, due to the high level of herding which causes investors to follow the decisions of the majority of other investors by the aim to reduce risk and increase the return in investment decision making. Risk perception does not influence investment decisions, due 
to a lack of caution towards investors and too bold an investment in uncertain stocks. Riskaverse does not influence investment decisions, because investors enjoy risk and decide to invest with high risk in making their investment decisions. Financial literacy does not influence investment decisions, which is caused by the lack of knowledge that investors have in investing with a high level of risk.

\section{Conceptual Framework}

The framework in this study can be described as in the following figure:

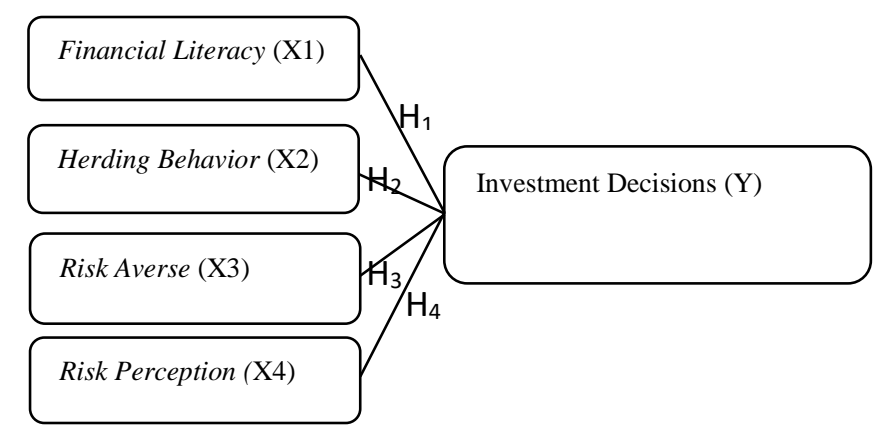

Figure 1. conceptual framework

Research Hypothesis:

H1: Financial literacy has a positive effect on investment decisions in generation $\mathrm{Z}$ and the millennial generation.

$\mathrm{H} 2$ : Herding has a positive effect on investment decisions in generation $\mathrm{Z}$ and the millennial generation.

H3: Risk-averse has a positive effect on investment decisions in generation $\mathrm{Z}$ and the millennial generation.

H4: Risk perception affects investment decisions in generation $\mathrm{Z}$ and the millennial generation.

\section{RESEARCH METHODS \\ Operational Definition}

Table 1. Operational Definition

\begin{tabular}{|c|c|c|c|}
\hline Variable & Operational Definition & Measurement Indicators & Scale \\
\hline $\begin{array}{l}\text { Finance Literacy } \\
(\mathrm{X} 1)\end{array}$ & $\begin{array}{l}\text { A series of processes or activities } \\
\text { to increase the knowledge } \\
\text { (knowledge), confidence } \\
\text { (confidence), skills (skills) of } \\
\text { consumers and the wider } \\
\text { community so that they can } \\
\text { manage finances better (OJK) }\end{array}$ & $\begin{array}{l}\text { 1. General knowledge of } \\
\text { personal finance } \\
\text { 2. Investation } \\
\text { 3. Economic conditions } \\
\text { 4. Personal finance } \\
\text { budget }\end{array}$ & Likert $(1-5)$ \\
\hline
\end{tabular}




\begin{tabular}{|c|c|c|c|}
\hline Herding (X2) & $\begin{array}{l}\text { Herding behavior is a follow-up } \\
\text { behavior by one investor } \\
\text { following another for various } \\
\text { reasons and conditions. This } \\
\text { behavior is the most common } \\
\text { mistake in which investors tend } \\
\text { to follow the majority in making } \\
\text { investment decisions. (Liem, } \\
\text { Sakamulia, 2007) }\end{array}$ & $\begin{array}{l}\text { 1. The influence of other } \\
\text { investors' decisions } \\
\text { 2. The influence of other } \\
\text { investors' decisions in } \\
\text { investment } \\
\text { transactions } \\
\text { 3. Reaction to changes } \\
\text { in other investors' } \\
\text { decisions }\end{array}$ & Likert $(1-5)$ \\
\hline Risk Averse (X3) & $\begin{array}{l}\text { Risk-Averse is the attitude of an } \\
\text { investor who avoids risk or it can } \\
\text { be said that the investor is only } \\
\text { willing to invest if the expected } \\
\text { return will be greater than the } \\
\text { risk (Sudana \& Sallama, 2015). }\end{array}$ & $\begin{array}{l}\text { 1. The influence of other } \\
\text { investors' decisions } \\
\text { 2. The influence of other } \\
\text { investors' decisions in } \\
\text { investment } \\
\text { transactions } \\
\text { 3. Reaction to changes } \\
\text { in other investors' } \\
\text { decisions }\end{array}$ & Likert $(1-5)$ \\
\hline $\begin{array}{l}\text { Risk Perception } \\
\text { (X4) }\end{array}$ & $\begin{array}{l}\text { Risk perception is a belief, } \\
\text { whether rational or irrational, } \\
\text { held by individuals, groups, or } \\
\text { society about the likelihood of a } \\
\text { risk occurring or about the } \\
\text { degree, magnitude, and timing of } \\
\text { its effects. (Kharta \& Kumar, } \\
\text { 2014) }\end{array}$ & $\begin{array}{l}\text { 1. Knowledge of } \\
\text { investment risks } \\
\text { 2. Assess the safety and } \\
\text { risks involved in } \\
\text { investing } \\
\text { 3. Attitude towards } \\
\text { investment risk }\end{array}$ & Likert $(1-5)$ \\
\hline $\begin{array}{l}\text { Keputusan } \\
\text { Investasi (Y) }\end{array}$ & $\begin{array}{l}\text { Putra et al (2016) define that } \\
\text { investment is an activity of } \\
\text { investing, either directly or } \\
\text { indirectly with the hope that, in } \\
\text { time, the owner of the capital } \\
\text { will get some benefits from the } \\
\text { investment. }\end{array}$ & $\begin{array}{l}\text { 1. Investment objectives } \\
\text { 2. Understanding of } \\
\text { investment growth } \\
\text { 3. Estimate the return on } \\
\text { investment } \\
\text { 4. Adequacy of } \\
\text { investment funds }\end{array}$ & Likert $(1-5)$ \\
\hline
\end{tabular}

\section{Population and sample}

In this study, the population is the entire academic community and students in the Mercu Buana University Campus environment. The determination of the research location is based on the limitations of the researcher, while to obtain a sample that can describe the population, in determining the sample of this study are the civitas and students at the Faculty of Economics and Business, Mercu Buana University who already have an income, which includes: Lecturers, Staff and students aged 15 - 39 years.

\section{Data collection technique}

To collect data, data collection techniques were used through a questionnaire or questionnaire, namely data collection through a closed list of questions in the form of a list of 
questions about the research problem that had to be filled in by respondents without the presence of the researcher. To produce the expected answer, the questionnaire is given a filling guide, simple language, and question items according to the study problem.

\section{Data Analysis Techniques}

Data analysis methods that will be used by the author in analyzing data using the SPSS program with the following stages:

\section{a. Descriptive Analysis}

Descriptive analysis is a statistic used to analyze data by describing data that has been collected as it is without intending to make conclusions that apply to the public or generalization (Sugiyono, 2013).

b. Data Quality Test

\section{Test Validity's[-pi]}

Validity test is done to measure the validity or validity of a questionnaire. Measuring validity can be done by correlating the scores of question items by comparing the value of $r$ arithmetic with $r$ tables for degree of freedom $(d f)=n-2$, where $(n)$ is the number of research samples. If $r$ arithmetic $>r$ table and a positive value then the item or question or indicator is declared valid (Ghozali, 2009).

2. Reliability Test

A reliability test is a tool used to measure the consistency of the questionnaire which is an indicator of a variable or construct. A construct. A constructor variable is declared reliable if the Cronbach Alpha value> 0.60 (Ghozali, 2009).

c. Classic assumption test

\section{Normality Testistepi}

The normality test aims to test whether in the regression model, the dependent and independent variables both have normal distributions or not. The classic assumption test for normality uses the Kolmogorov-Smirnov test, with this test data can be known to use normally distributed or not. If asump. sig. (2-tailed)> 0.05 , then the data is normally distributed and vice versa. (Santoso, 2002).

\section{Multicollinearity Test}

Multicollinearity test aims to test whether there is a correlation between independent variables (independent). A good model should not occur between the independent variables. Detection of the presence or absence of multicollinearity, namely by analyzing tolerance values and Variance Inflation Factors (VIF) $<10$ and tolerance values $>0.1$ (Ghozali, 2009).

\section{Heteroscedasticity Test}

The heteroscedasticity test is to test whether in the regression model there is an unequal variance from the residuals of one observation to another. If the variance from one observation residual to another observation is fixed, then it is called homoscedasticity and if the variance is different it is called heteroscedasticity. A good regression model is a homoscedasticity or heteroscedasticity does not occur (Ghozali, 2009).

d. Multiple Linear Regression Analysis Test

Multiple linear regression analysis is used to determine the effect caused by the independent variable indicators of the dependent variable with the following formulation (Sugiyono, 2013): 
$\mathrm{Y}=\propto+\beta \_1$ FLiteracy $+\beta \_2$ HBehavior $+\beta \_3$ RAverse $+\beta \_4$ RPerception $+\epsilon$

a. Hypothesis testing

Determination Coefficient Test (R2)

This test aims to find out how much the ability of the independent variables to explain the dependent variable by looking at the magnitude of the coefficient of total determination (R2). A value close to one means that the independent variables provide almost all the information needed to predict variations in the dependent variable (Ghozali, 2009).

b. Statistical Test $\mathrm{t}$

Statistical test $t$ is a test to find out how far the influence of one independent variable individually in explaining the variation of the dependent variable. According to Priyatno (2014), the basis for decision making can be done by looking at the probability of its significance, namely:

1) If the probability of significance $>0.05$ then $\mathrm{Ho}$ is accepted and $\mathrm{Ha}$ is rejected.

2) If the significance probability is $<0.05$ then Ho is rejected and $\mathrm{Ha}$ is accepted.

\section{FINDINGS AND DISCUSSION}

1. Data Quality Test Results

a. Validation Test Results

The following are the results of the instrument validity test:

a) Financial Literacy

Table 2. Validation Test Results of financial literacy

\begin{tabular}{|l|l|l|l|}
\hline Question Item & R count & R table & Information \\
\hline FL_1 & 0,254 & 0,159 & Valid \\
\hline FL_2 & 0,287 & 0,159 & Valid \\
\hline FL_3 & 0,383 & 0,159 & Valid \\
\hline FL_4 & 0,337 & 0,159 & Valid \\
\hline FL_5 & 0,287 & 0,159 & Valid \\
\hline
\end{tabular}

Source : SPSS Output Results, 2020

b) Herding Behavior

Table 3. Validation Test Results of Herding Behavior

\begin{tabular}{|l|l|l|l|}
\hline Question Item & R count & R table & Information \\
\hline HB_1 & 0,339 & 0,159 & Valid \\
\hline HB_2 & 0,220 & 0,159 & Valid \\
\hline HB_3 & 0,287 & 0,159 & Valid \\
\hline
\end{tabular}

Source : SPSS Output Results, 2020

c) Risk Averse

Table 4. Validation Test Results of Risk Averse

\begin{tabular}{|l|l|l|l|}
\hline Question Item & R count & R table & Information \\
\hline RA_1 & 0,520 & 0,159 & Valid \\
\hline RA_2 & 0,622 & 0,159 & Valid \\
\hline RA_3 & 1 & 0,159 & Valid \\
\hline
\end{tabular}

Source : SPSS Output Results, 2020 
d) Risk Perception

Table 5. Validation Test Results of Risk Perception

\begin{tabular}{|l|l|l|l|}
\hline Question Item & R count & R table & Information \\
\hline RP_1 & 0,189 & 0,159 & Valid \\
\hline RP_2 & 0,222 & 0,159 & Valid \\
\hline RP_3 & 0,355 & 0,159 & Valid \\
\hline RP_4 & 0,390 & 0,159 & Valid \\
\hline
\end{tabular}

Source : SPSS Output Results, 2020

e) Keputusan Investasi

Table 6. Validation Test Results of Investation decision

\begin{tabular}{|l|l|l|l|}
\hline Question Item & R count & R table & Information \\
\hline PKI_1 & 0,434 & 0,159 & Valid \\
\hline PKI_2 & 0,387 & 0,159 & Valid \\
\hline PKI_3 & 0,341 & 0,159 & Valid \\
\hline PKI_4 & 0,470 & 0,159 & Valid \\
\hline PKI_5 & 0,517 & 0,159 & Valid \\
\hline
\end{tabular}

Source : SPSS Output Results, 2020

b. Reliability test results

Table 7. Reliability Test Results

\begin{tabular}{|c|c|c|c|c|}
\hline \multicolumn{5}{|c|}{ Item-Total Statistics } \\
\hline & $\begin{array}{l}\text { Scale Mean if } \\
\text { Item Deleted }\end{array}$ & $\begin{array}{l}\text { Scale Variance if } \\
\text { Item Deleted }\end{array}$ & $\begin{array}{l}\text { Corrected } \\
\text { Item-Total } \\
\text { Correlation }\end{array}$ & $\begin{array}{l}\text { Cronbach's } \\
\text { Alpha if Item } \\
\text { Deleted }\end{array}$ \\
\hline PKI_1 & 222.39 & 593.213 & .557 & .737 \\
\hline PKI_2 & 222.75 & 585.491 & .575 & .734 \\
\hline PKI_3 & 223.47 & 570.788 & .710 & .726 \\
\hline PKI_4 & 223.16 & 579.557 & .673 & .730 \\
\hline PKI_5 & 222.61 & 587.352 & .633 & .734 \\
\hline $\mathrm{FL} \_1$ & 222.22 & 599.459 & .383 & .740 \\
\hline FL_2 & 223.12 & 592.397 & .431 & .737 \\
\hline FL_3 & 223.39 & 584.588 & .481 & .734 \\
\hline $\mathrm{FL} \_4$ & 222.54 & 595.850 & .418 & .739 \\
\hline $\mathrm{FL}$ 5 & 222.09 & 604.910 & .330 & .743 \\
\hline HB_1 & 223.66 & 569.337 & .681 & .726 \\
\hline HB_2 & 223.83 & 574.457 & .545 & .730 \\
\hline HB_3 & 224.01 & 573.925 & .519 & .730 \\
\hline RP_1 & 223.56 & 577.773 & .529 & .731 \\
\hline RP_2 & 223.01 & 585.762 & .489 & .734 \\
\hline RP_3 & 223.18 & 582.199 & .574 & .732 \\
\hline RP_4 & 223.14 & 593.661 & .371 & .738 \\
\hline RA_1 & 222.48 & 590.351 & .554 & .736 \\
\hline RA_2 & 222.42 & 593.045 & .624 & .737 \\
\hline RA_3 & 222.78 & 583.562 & .634 & .732 \\
\hline TOTALSKOR & 114.35 & 153.855 & 1.000 & .884 \\
\hline
\end{tabular}

Source : SPSS Output Results, 2020 
Reliability Statistics

Cronbach's

\begin{tabular}{ll} 
Alpha & N of Items \\
\hline .745 & 21 \\
\hline
\end{tabular}

\section{Classic Assumption Test}

a. Normality Test

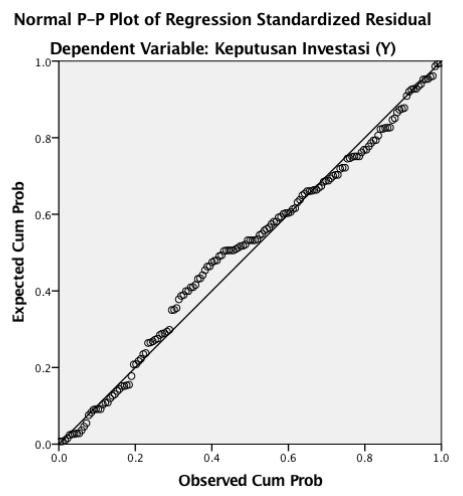

b. Multikoleniarity test

Figure 2. Results of the normality test

Table 8. Results of the Multikoleniarity test

Coefficients $^{\mathrm{a}}$

\begin{tabular}{|c|c|c|c|c|c|c|c|c|}
\hline \multicolumn{2}{|c|}{ Model } & \multicolumn{2}{|c|}{$\begin{array}{l}\text { Unstandardized } \\
\text { Coefficients }\end{array}$} & $\begin{array}{l}\text { Standardiz } \\
\text { ed } \\
\text { Coefficient } \\
\mathrm{s}\end{array}$ & t & Sig. & \multicolumn{2}{|c|}{$\begin{array}{l}\text { Collinearity } \\
\text { Statistics }\end{array}$} \\
\hline \multirow[t]{5}{*}{1} & (Constant) & 1.056 & 2.361 & & .447 & .655 & & \\
\hline & Financial Literacy (X1) & .320 & .090 & 242 & 3.553 & .001 & .663 & 1.508 \\
\hline & Herging Behavior (X2) & .201 & .059 & .206 & 3.411 & .001 & .847 & 1.181 \\
\hline & Risk Averse (X3) & .206 & .076 & .181 & 2.715 & .007 & .692 & 1.445 \\
\hline & Risk Perception (X4) & .596 & .128 & .336 & 4.640 & .000 & .587 & 1.703 \\
\hline
\end{tabular}

a. Dependent Variable: Investment Decisions (Y)

c. Heteroscedasticity test 


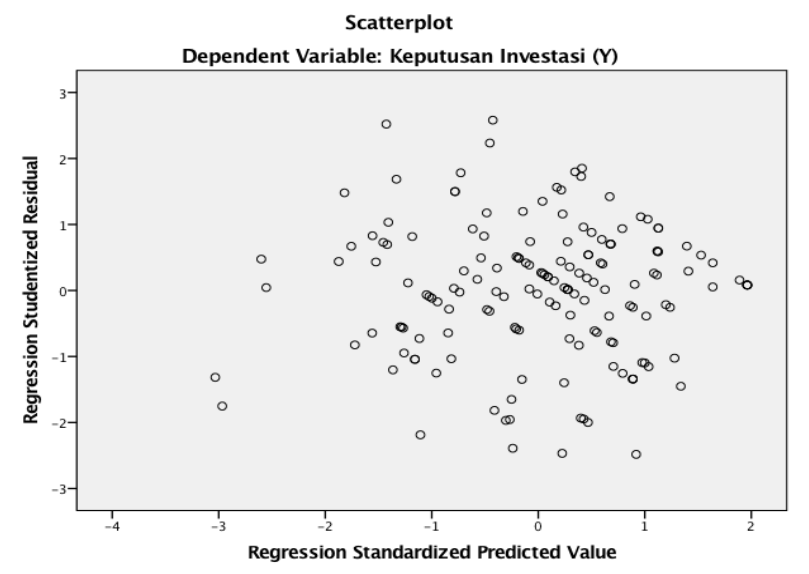

Figure 3. Results of the Heteroscedacity test

\section{Hypothesis test results}

The results of multiple linear regression analysis

Tabel 9. Multiple linear regression test results

Coefficients $^{\mathrm{a}}$

\begin{tabular}{|c|c|c|c|c|c|c|c|c|}
\hline \multicolumn{2}{|c|}{ Model } & \multicolumn{2}{|c|}{$\begin{array}{c}\text { Unstandardized } \\
\text { Coefficients } \\
\text { Std. }\end{array}$} & \multicolumn{2}{|c|}{$\begin{array}{l}\text { Standardized } \\
\text { Coefficients }\end{array}$} & Sig. & \multicolumn{2}{|c|}{$\begin{array}{l}\text { Collinearity Statistics } \\
\text { Toleranc }\end{array}$} \\
\hline 1 & (Constant) & 1.056 & 2.361 & & .447 & .655 & & \\
\hline & Financial Literacy (X1) & .320 & .090 & .242 & 3.553 & .001 & .663 & 1.508 \\
\hline & Herding Behavior (X2) & .201 & .059 & .206 & 3.411 & .001 & .847 & 1.181 \\
\hline & Risk Averse (X3) & .206 & .076 & 181 & 2.715 & .007 & .692 & 1.445 \\
\hline & Risk Perception (X4) & .596 & .128 & .336 & 4.640 & .000 & .587 & 1.703 \\
\hline
\end{tabular}

a. Dependent Variable: Investment Decisions (Y)

4. Hypothesis Test Results

a. Coefficient Determination $\left(\mathrm{R}^{2}\right)$

\section{Table 10. Results of Coefficient Determination $\left(\mathbf{R}^{2}\right)$}

\begin{tabular}{|c|c|c|c|c|c|}
\hline \multicolumn{6}{|c|}{ Model Summary ${ }^{b}$} \\
\hline & & & Adjusted R & Std. Error of the & \\
\hline Model & $\mathrm{R}$ & R Square & Square & Estimate & Durbin-Watson \\
\hline 1 & $.720^{a}$ & .519 & .507 & 2.784 & 1.925 \\
\hline
\end{tabular}

b. F test 
Table 11. Results of F-Test

\begin{tabular}{|c|c|c|c|c|c|c|}
\hline \multicolumn{7}{|c|}{ ANOVA $^{a}$} \\
\hline \multirow[t]{3}{*}{1} & Regression & 1304.405 & 4 & 326.101 & 42.087 & $.000^{b}$ \\
\hline & Residual & 1208.725 & 156 & 7.748 & & \\
\hline & Total & 2513.130 & 160 & & & \\
\hline
\end{tabular}

a. Dependent Variable: Investment Decisions (Y)

b. Predictors: (Constant), Risk Perception (X4), Herging Behavior (X2), Risk Averse (X3), Financial Literacy (X1)

c. T test

Table 12. Results of $T$ Test

Coefficients $^{\mathrm{a}}$

\begin{tabular}{|c|c|c|c|c|c|c|}
\hline \multicolumn{2}{|c|}{ Model } & \multicolumn{2}{|c|}{$\begin{array}{c}\text { Unstandardized } \\
\text { Coefficients } \\
\text { Std. }\end{array}$} & $\begin{array}{l}\text { Standardized } \\
\text { Coefficients } \\
\text { Beta }\end{array}$ & $\mathrm{t}$ & Sig. \\
\hline 1 & (Constant) & 1.056 & 2.361 & & .447 & .655 \\
\hline & Financial Literacy (X1) & .320 & .090 & .242 & 3.553 & .001 \\
\hline & Herding Behavior (X2) & .201 & .059 & .206 & 3.411 & .001 \\
\hline & Risk Averse (X3) & .206 & .076 & .181 & 2.715 & .007 \\
\hline & Risk Perception (X4) & .596 & .128 & .336 & 4.640 & .000 \\
\hline
\end{tabular}

a. Dependent Variable: Investment Decisions (Y)

\section{Discussion}

The results of regression calculations in this study show that the financial literacy variable has a significance value of 0.00 where this value is smaller than the error tolerance limit of 0.05 , so it can be concluded that $\mathrm{H} 1$ is accepted, which means the financial literacy variable has a significant positive effect on investment decisions. Therefore, the investment decision making by Generation $\mathrm{Z}$ and Millennial Generation respondents in the academic community of the Faculty of Economics and Business, Mercu Buana University is influenced by the financial literacy they know or understand. The higher a person's literacy level, the better his decision making is. This research is in line with research conducted by Pritazahara \& Sriwidodo (2015), Putri \& Rahyuda (2017). Dewi, Iga \& Purbawangsa, Ida (2018) and Setyanto, Dihin (2019).

In this study, it was able to prove that the respondents were affected by the deviations in the investment behavior of herding behavior. This can be seen in the calculation results shown by the t-test used to measure that the herding behavior variable has an effect on investment decisions and the result is a significance value of 0.01 which is smaller than the error tolerance limit of 0.05 . So it can be concluded that the significance value of the herding behavior variable has a significant positive effect on investment decisions.

The results of the calculation of this study show that the variable risk averse has a significance value of 0.007 which means it is smaller than 0.05 , so that $\mathrm{H} 3$ is accepted. So it can be concluded that Risk Averse has a positive effect on investment decisions. Therefore, the investment decision making by Generation $\mathrm{Z}$ and Millennial Generation respondents in 
the academic community of the Faculty of Economics and Business, University of Mercu Buana has an attitude that tends to avoid risk or it can be said that investors are only willing to invest if the expected return is greater than risk (Sudana \& Sallama, 2015). Investors with the risk averter type have the goal of avoiding losses so as not to make wrong investment decisions (Irjayanti, 2017).

The results of the calculation of this study indicate that the risk perception variable has a significance value of 0,000 , which means it is smaller than 0.05 , so $\mathrm{H} 4$ is accepted. So it can be concluded that Risk Perception has a positive effect on investment decisions. Therefore, the investment decision making by Generation $\mathrm{Z}$ and Millennial Generation respondents in the academic community of the Faculty of Economics and Business, Mercu Buana University, tends to be careful in dealing with risks. Investors tend to choose to have investments in definite stocks, so it can be seen if investors are very careful when making decisions and take more consideration when making decisions.

\section{CONCLUSION AND SUGESTION}

\section{Conclusion}

Based on the results of data analysis obtained through questionnaires distributed to respondents, the following conclusions were obtained: (1) Financial Literacy, has a positive effect on investment decision making. The better the level of financial literacy the respondent has, the better the investment decision will be. (2) Herding Behavior has a positive effect on student investment decisions. So it can be concluded that the significance value of the herding behavior variable has a significant positive effect on the respondent's investment decision. Respondents' investment decisions that are influenced by the herding behavior variable tend to rely more on other people's decisions in making their investment decisions. (3) Risk Averse has a positive effect on investment decisions. Therefore, the respondent's investment decision making tends to avoid risk or it can be said that the investor is only willing to invest if the expected return is greater than the risk. (4) Risk Perception has a positive effect on investment decisions. Respondents' investment decision making tends to be cautious in dealing with risks. Investors tend to choose to have investments in definite stocks, so it can be seen if investors are very careful when making decisions and take more consideration when making decisions.

\section{Suggestion}

1. For further researchers, with this research it is hoped that further research will be able to carry out research related to financial behavior because there are still many other factors that can influence financial behavior, especially investment decisions. Because this topic really needs to be discussed to improve good financial behavior for future generations, especially the millennial generation.

2. For Generation $\mathrm{Z}$ and Millennial Investors, it is important to increase confidence and confidence in making investment decisions so that all decisions do not depend on the decisions of others.

\section{REFERENCE}

Arif, Kashif. (2015). Financial Literacy And Other Factors Influencing Individuals' Investment Decision: Evidence From A Developing Economy (Pakistan). Journal Of Poverty, Investment And Development, Vol. 12 
Ateş, Sinem; Coşkun, Ali; Şahin, M. Abdullah \& Demircan, M. Levent. (2016). Impact Of Financial Literacy On The Behavioral Biases Of Individual Stock Investors: Evidence From Borsa Istanbul. Business And Economics Research Journal, Vol. 7, No. 3, Pp. $1-19$

Farooq, A., \& Sajid, M. (2015). Factors Affecting Investment Decision Making: Evidence from Equity Fund Managers and Individual Investors in Pakistan. Research Journal of Finance and Accounting, 6(9), 319-324.

Fedorova, Elena Anatol'evna; Nekhaenko, Viktoriya Vikrovna \& Dovzhenko, Sergei Eugen'evich. (2015). Impact of Financial Literacy Of The Population Of The Russian Federation On Behavior On Financial Market: Empirical Evaluation. Russian Economic Develompment, Vol. 26, No. 4, Pp. 394-402.

Gozalie \& Anastasia, 2015. Pengaruh Perilaku Heuristics dan Herding Terhadap Pengambilan Keputusan Investasi Properti Hunian. FINESTA. Vol 3. No 2. Hal 28-32

Ghozali, Imam. (2009). Aplikasi Analisis Multivariate dengan Program SPSS. Semarang. Badan Penerbit UNDIP.

Howe, N., \& Strauss, W. (2000). Millennials rising: The next great generation. New York: Vintage.

Hussain, Dr. Irshad \& Sajjad, Prof. Dr. Shahida. (2016). Significance Of Financial Literacy And Its Implications: A Discussion. Journal Of Business Strategies, Vol.10, No.2, Pp 141- 154 .

Irjayanti, D. (2017). Pengaruh Literasi Keuangan, Representativeness, Familiarity, dan Persepsi Risiko Terhadap Pengambilan Keputusan Investasi Pada Investor Surabaya dan Sidoarjo.

Jurnal Ilmu Manajemen, 5(9), 1-17.Kharta, S., \& Kumar, S. R. (2014). Influence of Risk Perception of Investors on Investment Decisions: An Empirical Analysis. Journal of Finance and Bank Management, 2(2), 15-25.

Liem, W. K. A., \& Sukamulja, J. S. (2017). Perilaku Herding Pada Indeks Sektoral dan Saham-Saham

Terpilih. Mycological Research, 113(2), 207-221.Lutfi. (2010). The Relationship Between Demographic Factors And Investment Decision In Surabaya. Journal of Economics, Business And Accountancy Ventura, Vol. 13, No. 3, Pages 213 - 224 63.

MERTHA DEWI, IGA; PURBAWANGSA, Ida Bagus Anom. Pengaruh literasi keuangan, pendapatan serta masa bekerja terhadap perilaku keputusan investasi. E-Jurnal Ekonomi dan Bisnis Universitas Udayana, [S.1.], p. 1867-1894, july 2018.

Otoritas Jasa Keuangan. (2017). Strategi Nasional Literasi Keuangan Indonesia (Revisit 2017).

Parmariza dan Juniarti. (2017). Pengaruh Persepsi Resiko, Persepri Kebermanfaatan dan Gaya Hidup yang Dianut terhadap Perilaku Penggunaan Kartu Kredit. Jurnal Ilmiah Manajemen dan Bisnis, Vol 3 No. 01 Maret 2017. 
Pratiwi, Indah \& Priajati. (2015). Pengaruh Faktor Demografi Terhadap Jenis Investasi Dan Perilaku Investor Pasar Modal Surabaya. Jurnal Ilmu Dan Riset Manajemen, Vol. 4, No. 7.

Pritazahara, Ritma \& Sriwidodo, Untung. (2015). Pengaruh Pengetahuan Keuangan Dan Pengalaman Keuangan Terhadap Perilaku Perencanaan Investasi Dengan Self Control Sebagai Variabel Moderating. Jurnal Ekonomi Dan Kewirausahaan, Vol. 28, No. 1: 28- 37

Priyatno, Duwi. (2014). SPSS 22: Pengolah Data Terprakatis. Yogyakarta. CV. Andi Offset.

Putri, Ramadhani \& Isbanah, Y (2020). Faktor-Faktor Yang Memengaruhi Keputusan Investasi Pada Investor Saham Di Surabaya. Jurnal Ilmu Manajemen Vol. 8 No 1.

Putri \& rahyuda (2017). Pengaruh Tingkat Financial Literacy Dan Faktor Sociodemografi Terhadap Perilaku Keputusan Investasi Individu. Jurnal Ekonomi Dan Bisnis Universitas Udayana, 6(9), 3407-3434.

Ranjbar, M., et al, 2014. Analyzing the Effective Behavioral Factors on the Investors' Performance in Tehran Stock Exchange (Tse).

Santoso, Singgih. (2002). Statistik Parametrik. Cetakan ketiga. Jakarta. PT. Gramedia Pustaka Utama.s[ép]

Setyanto, Dihin (2019). Faktor-Faktor Yang Mempengaruhi Investor Individu Dalam Pengambilan Keputusan Investasi Sekuritas Di Bursa Efek Indonesia (BEI)

Sudana, I. M., \& Sallama, N. I. (2015). Manajemen Keuangan Perusahaan Teori dan Praktik. Jakarta:

ErlanggaSugiyono. (2013). Metode Penelitian Bisnis. Bandung. Alfabeta.

Ullah, S. (2015). An Empirical Study of Illusion of Control and Self-Serving Attribution Bias, Impact on Investor 's Decision Making: Moderating Role of Financial Literacy. Journal of Finance

and Accounting, 6(19), 109-118.Umar, Husein. (2013). Desain Penelitian MSDM dan Perilaku Karyawan Paradigma Positivistik dan Berbasis Pemecahan Masalah. Jakarta. PT Raja Grafindo Persada.

Vijaya (2014). “An Empirical Analysis of Influential Factors On Investment Behaviour of Retail Investors' in Indian Stock Market: A Behavioural Perspective".

Vijaya (2016). An Empirical Analysis on Behavioural Pattern of Indian Retail Equity Investors. 